\title{
Chronic Pain - Perceptions, Limitations and Implications. A Social Perspective
}

\author{
Dor Crónica - Percepções, Limitações e Implicações. Uma Perpectiva Social \\ Maria Carolina Monteiro ${ }^{1 *}$, Paulo Reis-Pina ${ }^{2}$ \\ ${ }^{1}$ Instituto da Segurança Social, IP Lisboa \\ ${ }^{2}$ Instituto Português de Oncologia de Lisboa Francisco Gentil, EPE. , Lisboa \\ Email: mcarolinamonteiro@sapo.pt \\ *This work was developed as part of the Master in Continuous Care (Universidade Lusófona, Lisboa)
}

\begin{abstract}
Chronic pain (CP) is a complex phenomenon that affects the lives of individuals at the level of well-being, family relationships and social and professional life, causing biological and psychosocial changes, and in most cases, suffering. CP is associated with physical, professional and social limitations, and compromises quality of life (QOL) provoking insecurity which results in considerable social and material losses. In this context a multidimensional pain assessment is fundamental in order to find a swift and appropriate response to the needs of each individual. The evaluation should take into account psychological and social factors in addition to physical factors.

pain (CP) is a complex phenomenon that affects the lives of individuals at the level of well-being, family relationships and social and professional life, causing biological and psychosocial changes, and in most cases, suffering. CP is associated with physical, professional and social limitations, and compromises quality of life (QOL) provoking insecurity which results in considerable social and material losses. In this context a multidimensional pain assessment is fundamental in order to find a swift and appropriate response to the needs of each individual. The evaluation should take into account psychological and social factors in addition to physical factors.

The authors of this paper reinforce the idea that any evaluation and / or intervention that is made in people with CP must always take into account the internal and external factors of the environment in which the individual belongs, and which influence how they perceive and assess their pain
\end{abstract}

Keywords: Chronic pain; biopsychosocial model; well-being; quality of life, suffering.

\begin{abstract}
Resumo
A dor crónica (DC) é um fenómeno complexo que interfere na vida dos indivíduos ao nível do bem-estar, nas relações familiares e sociais, e na vida profissional, provocando alterações biológicas, psicossociais e, na maioria das vezes, sofrimento. Associada às limitações físicas, profissionais e sociais, a DC compromete a qualidade de vida (QDV) e promove a insegurança, resultando em perdas materiais e sociais consideráveis. Neste contexto é fundamental uma abordagem multidimensional na avaliação da dor, de modo a encontrar uma resposta célere e adequada às necessidades de cada indivíduo. A avaliação deve ter em conta, além dos factores físicos, os factores psicológicos e os sociais.

Os autores, neste artigo, reforçam a ideia que, qualquer avaliação e/ou intervenção que seja feita em pessoas com DC, deve ter sempre em conta os factores internos e externos do meio em que o indivíduo está inserido e que influenciam o modo como este percepciona e avalia a sua dor.
\end{abstract}

Palavras-chave: Dor crónica; modelo biopsicossocial; bem-estar; qualidade de vida, sofrimento. 


\section{Introduction}

Pain is a major factor that affects the full experience of a human being, whether in our individuality, in our private life or the socio-economic environment in which we operate. Pain restricts QOL, weakens the capabilities and limits human qualities. Pain constitutes a unique experience as it is subjective and personal. Each individual has their culture on pain which is conditioned by the biological, psychological, social, emotional, cultural and spiritual needs of that person ${ }^{[1]}$.

According to the 'International Association for the Study of Pain' (IASP), pain is a multidimensional unpleasant experience. It involves sensory and emotional components, is usually associated with actual or potential tissue damage, and described according to the lesion ${ }^{[2]}$. $\mathrm{CP}$ is characterized as a persistent or recurrent pain lasting for at least 3-6 months and one which often persists beyond the healing of the injury that caused it, or where there is no apparent injury ${ }^{[2]}$. This type of pain is usually associated with chronic disease processes that cause continuous or recurrent pain ${ }^{[1]}$, conditioning limitations and disabilities that are reflected at the level of employment, social life and family ${ }^{[3]}$. In addition to affecting relationships, personal interaction and even the carrying out of daily life activities, CP most often becomes an increased economic burden which depletes the individual and those around them, both in physical and mental resources ${ }^{[4,5]}$.

In many areas of knowledge there are various definitions for the concept of pain, some of which are more targeted towards healthcare and others more relevant to the psychosocial sphere. In this context, pain may be associated with a set of negative images resulting from either direct or indirect experiences of an individual such as prolonged suffering, the absence of treatment, abuse of and addiction to drugs ${ }^{[3]}$. This becomes a serious problem for the individual, their family and network of relationships because it limits and governs the behavior and living conditions of those involved ${ }^{[5,6]}$. The negative impacts it has on many aspects of life are associated with a significant decline in functionality, social and family relationships and QOL $^{[5,7,8]}$.

In short, pain is a subjective sensation caused by physical and / or mental factors. We must pay attention to pain because the anguish and vulnerability that it causes in an individual may jeopardize their integrity [4].

\section{Introdução}

A dor é um dos principais factores que condiciona a vivência plena do ser humano, seja na sua individualidade, na sua vida privada ou no meio sócioeconómico em que está inserido. A dor coarcta a QDV, enfraquece as capacidades e limita as qualidades do ser humano. A dor congrega uma experiência única, subjectiva e intransmissível. Cada indivíduo possui a sua cultura sobre dor, condicionada pelos aspectos biológicos, psicológicos, sociais, emocionais, culturais e espirituais de cada $\operatorname{ser}^{[1]}$

Segundo a "International Association for the Study of Pain" (IASP), a dor é uma experiência multidimensional desagradável, que envolve componentes sensoriais e emocionais, geralmente associada a uma lesão tecidular concreta ou potencial, e descrita em função dessa lesão ${ }^{[2]}$. A DC é caracterizada como uma dor persistente ou recorrente durante pelo menos 3 a 6 meses e que muitas vezes persiste para além da cura da lesão que lhe deu origem, ou que existe sem lesão aparente ${ }^{[2]}$. Este tipo de dor está geralmente associado a processos patológicos crónicos que provocam dor contínua ou recorrente ${ }^{[1]}$, condicionando limitações e incapacidades que se reflectem a nível laboral, social e familiar ${ }^{[3]}$. No entanto, a DC, além ser factor limitador ao nível das relações, do convívio pessoal e até da realização das actividades da vida quotidiana, na maioria das vezes torna-se num encargo económico acrescido, que esgota o indivíduo e aqueles que o rodeiam, em termos físicos e psíquicos ${ }^{[4,5]}$.

Nas diversas áreas do conhecimento existem várias definições para o conceito de dor, sendo umas, mais direccionadas para a área da saúde e outras, mais para a área psicossocial. Nesse contexto, a dor pode estar associada a um conjunto de imagens negativas, resultantes de experiências vividas, directa ou indirectamente pelo indivíduo, como o sofrimento prolongado, a inexistência de tratamento, o excesso e dependência de medicamentos ${ }^{[3]}$. Torna-se num problema sério para ele, para a família e para rede de relações pois limita e direcciona o comportamento e as condições de vida dos envolvidos ${ }^{[5 ; 6]}$. Os impactos negativos que provoca em diversos aspectos da vida, estão associados a um declínio significativo da funcionalidade, dos relacionamentos sócio-familiares e da QDV ${ }^{[5 ; 7 ; 8] \text {. }}$

Em suma, a dor é uma sensação subjectiva, de origem física e/ou psíquica e à qual se deve estar atento dado que, a angústia e vulnerabilidade que a dor provoca num individuo podem por em causa a sua integridade ${ }^{[4]}$. 


\section{The Assessement of Pain as Complex, Subjective and Multidimensional}

It is accepted that pain is a complex, multidimensional and subjective phenomenon $\left.{ }^{[9,} 10,11\right]$ that requires multiple interventions because, if not properly and / or timely treated, it can influence the QOL of individuals. Pain not only affects the sufferer, it can also affect the people with whom the individual interacts. Pain can be considered as a 'biopsychossocial' phenomenon resulting from the combination of several factors, including biological, psychological, behavioral, social and cultural factors ${ }^{[12]}$. As such, in order to assess pain it is important to consider and understand its various dimensions. This inevitably requires a multidisciplinary approach that emphasizes the complex nature of pain ${ }^{[9]}$. The task is rarely easy, particularly in situations in which an individual manifests complaints without visible and objective signs of CP. In these cases the assessment cannot be limited purely to biological aspects ${ }^{[13,14]}$. Other aspects that may influence the whole process must be taken into account. Psychological factors such as mood disorders and anxiety as well as social aspects can play an important role in the existence and persistence of pain symptoms i.e. disease can induce unusual behavior, for example, the manifestation of exaggerated claims compared to minimal objective evidence $^{[10]}$.

There is emphasis on the importance of continued attention to the psychological and psychosocial aspects associated with pain perception, in addition to nonmedical matters such as financial issues. This highlights the importance of gaining a good understanding of patients with chronic pain, especially concerning the psychological and social aspects ${ }^{[13]}$.

Each individual has unique experiences of pain, values and expectations of life, cultural and emotional experiences which are conditioned by physiological and psychological aspects ${ }^{[4,9]}$.Therefore certain behaviors may be associated with social learning about the meaning of pain and expected behavior when pain is experiencd ${ }^{[7]}$. Psychosocial factors interfere in the way each individual perceives their pain and how they adapt or reject the limitations arising from this ${ }^{[3]}$, i.e. an individual feels, tolerates, perceives and transmits their unique form of pain according to interference factors that can be physical, psychological or social and / or cultural $^{[15]}$.

The factors affecting pain assessment may be multiple, so that it is necessary to use subjective methods in order to measure it $^{[16]}$. However, in order to analyze the extent to which CP causes disability and limitations in an individual, it is necessary to consider and evaluate factors external to the individual. These include sociodemographic characteristics, lifestyle, physical

\section{A Avaliação da Dor Enquanto Fenómeno Complexo, Multidimensional e Subjectivo}

Aceita-se que a dor é um fenómeno complexo, multidimensional e subjectivo ${ }^{[9 ; 10 ; 11]}$ que necessita de intervenções múltiplas porque, quando não adequadamente e/ou atempadamente tratada, influencia a QDV dos indivíduos. Não só dos que têm dor como a das pessoas com quem se relaciona. Pode ser considerada como um fenómeno "biopsicossocial" resultante da combinação de diversos factores, nomeadamente biológicos, psicológicos, comportamentais e socioculturais ${ }^{[12]}$. Como tal, para avaliar a dor importa considerar e entender as suas várias dimensões, o que obriga inevitavelmente a uma abordagem multidisciplinar que enfatize a sua natureza complexa ${ }^{[9]}$ Raramente se apresenta como tarefa fácil, particularmente nas situações em que o individuo manifesta queixas de DC sem sinais visíveis e/ou objectivos. Nestes casos a avaliação não pode ficar limitada aos aspectos puramente biológicos ${ }^{[13 ; 14]}$. Outros que podem influenciar todo o processo devem ser tidos em conta. Os aspectos psicológicos, como distúrbios do humor e ansiedade, bem como aspectos sociais, podem ter papel relevante na existência e manutenção de sintomas de dor ou seja, podem induzir comportamentos de doença pouco usuais, como por exemplo, a manifestação exacerbada de queixas comparadas com sinais objectivos diminutos ${ }^{[10]}$.

A importância da atenção continua sobre os aspectos psicológicos e psicossociais associados à percepção de dor, bem como a questões não-médicas como por exemplo, questões financeiras foi já enfatizada, chamando a atenção para uma boa compreensão dos doentes com dor crónica designadamente no que envolve os aspectos psicológicos e sociais ${ }^{[13]}$.

Cada indivíduo tem experiências únicas de dor, valores e expectativas de vida, culturais e emocionais, condicionadas por aspectos fisiológicos e psicológicos [4;9] pelo que se acredita que determinados comportamentos podem estar associados à aprendizagem social sobre o significado da dor e sobre o modo de se comportar quando a vivenciam ${ }^{[7]}$. Os factores psicossociais interferem na forma como cada indivíduo percepciona a sua dor e na forma de adaptação ou recusa às limitações decorrentes da mesma ${ }^{[3]}$, ou seja, um individuo sente, tolera, percepciona e transmite a sua dor de forma única, devido à interferência de factores que podem ser de ordem física, psicológica ou de âmbito social e/ou cultural $^{[15]}$.

Os factores que afectam a avaliação da dor podem ser múltiplos, pelo que, para mensurá-la, é necessário utilizar métodos subjectivos ${ }^{[16]}$. Mas, para analisar até que ponto a DC provoca incapacidade e limitações num indivíduo, é necessário considerar e avaliar 
and social environment, as well as internal factors such as cognitive and psychological factors, and experiences and expectations ${ }^{[17,18]}$. Hence the importance of a comprehensive assessment of functional state, and psychological and social state, rather than a restricted, superficial appraisa ${ }^{[16]}$.

From a psychosocial perspective, when the individual is assessed in their multidimensionality, it defines the sense of pain as a subjective and unpleasant experience. This is caused by a dynamic imbalance between physical and psychological aspects, interacting with the respective social environment ${ }^{[13]}$.

For a better understanding of how individual patients respond and react to pain, one must consider not only the biological and psychological factors, but also social factors that involve family members and / or caregivers with whom they interact ${ }^{[18]}$.

Close social relationships play an essential role in the life of every individual. In the case of chronic patients the absence or breakdown of these relationships, their existence and, in certain situations, the reinforcement they can provide, have marked effects on their life ${ }^{[19,20]}$. Several studies on the existence of supportive social relationships and the progression of chronic diseases revealed that the more there is this kind of support provided to the patient's satisfaction, the slower the development of chronic disease ${ }^{[14,19,21]}$. In this sense, the existence of social proximity seem to positively affect the overall well-being of individuals. These relationships play a key role in an individual's life, especially when they suffer from some kind of debilitating disease, because they affect the social, psychological and behavioral aspect of that individual $^{[2]]}$.

Psychological factors should always be considered because they influence the perception and evaluation of physiological signals and social factors, and behavioral responses are modeled according to the perceived physical changes ${ }^{[22]}$. In turn, these changes may be associated with physical disability, emotional disturbances and social difficulties. As such, the approach must assume a biopsychosocial perspective due to the existence of a connection between the biological, the psychological and social context ${ }^{[1,14]}$.

One of the common consequences of CP is isolation. Isolation because of the pain and the pain of isolation are often associated. This type of pain is the most difficult to solve because it is commonly associated with lack of company. It is a subjective pain and depends on the values of each individual. It provokes feelings of anxiety, threatens the individual's integrity and consequently increases their psychosocial vulnerability ${ }^{[4,20]}$. However, it is recognized that many individuals express pain through social isolation ${ }^{[16]}$. The interference of $\mathrm{CP}$ at the level of well-being, family and social relationships, and in professional life, factores externos ao indivíduo como as características sociodemográficas, o estilo de vida, o ambiente físico e social, e factores internos como, as capacidades cognitivas e psicológicas, as experiências vividas e as espectativas ${ }^{[17 ; 18]}$. Daí a importância de uma avaliação exaustiva do estado funcional, psíquico e social, não se restringindo a uma apreciação superficial ${ }^{[16]}$.

Numa perspectiva psicossocial, o indivíduo quando avaliado na sua multidimensionalidade, define o seu sentido de dor como uma experiência subjectiva e desagradável que resulta de um desequilíbrio dinâmico entre os aspectos físicos e psicológicos, e nas interacções com o ambiente social em que está inserido ${ }^{[13]}$.

Para uma melhor compreensão sobre o modo como determinados doentes respondem e reagem à dor, é necessário analisar não só os factores biológicos e psicológicos, mas também os factores sociais que os envolvem, os familiares e/ou cuidadores com quem ele se relacione ${ }^{[18]}$.

As relações sociais de proximidade têm um papel essencial na vida de todos os indivíduos. No caso dos doentes crónicos a inexistência ou quebra deste tipo de relações, bem como a sua existência e em determinadas situações o seu reforço, têm repercussões marcadas na vida dos mesmos ${ }^{[19 ; 20]}$. Diversos estudos realizados sobre as relações sociais de apoio e a progressão de doenças crónicas revelaram que quanto mais existir este tipo de suporte e se revelar satisfatório para o doente, mais lenta é a evolução da doença crónica ${ }^{[14 ; 19 ; 21]}$. Nesse sentido, a existência de relações sociais de proximidade parecem afectar, de forma positiva, o bem-estar geral dos indivíduos. Estas relações têm um papel fundamental na vida de um indivíduo, principalmente se este sofrer de algum tipo de doença incapacitante, porque interferem na dimensão social, psicológica e comportamental ${ }^{[21]}$.

Os factores psicológicos devem ser sempre considerados pois influenciam a capacidade de avaliação e percepção dos sinais fisiológicos e dos factores sociais, modelando as respostas comportamentais de acordo com a percepção das suas alterações físicas ${ }^{[22]}$. Por sua vez, estas alterações podem ser associadas à incapacidade física, a perturbações emocionais e a dificuldades sociais Como tal, a abordagem deve assumir uma perspectiva biopsicossocial pela existência de conexão entre as alterações biológicas, o estado psicológico e o contexto social $^{[1 ; 14]}$.

Uma das consequências frequente da DC é o isolamento. $\mathrm{O}$ isolamento por causa da dor e a dor do isolamento são uma associação constante. É um tipo de dor das mais difíceis de resolver pois está associada, muitas vezes, à falta de companhia. É uma dor subjectiva e depende dos valores de cada um. Provoca angústia, ameaça a integridade e consequentemente aumenta a vulnerabilidade psicossocial do indivíduo ${ }^{[4 ; 20]}$. Não obstante, admite-se que muitos indivíduos expressam a dor através do isolamento social ${ }^{[16]}$. 
results in biological changes and psychosocial distress ${ }^{[18]}$. In other words, when associated with physical limitations, professional and social chronic pain affects the quality of life and causes insecurity, resulting in considerable social and material losses ${ }^{[10,22]}$.

\section{Some Facts About The Reality of Chronic Pain}

In systematic reviews prevalence estimates ranged from CP 2-55\% [23, 24]. Breivik et al found in fifteen European countries prevalence of $\mathrm{CP}$ ranging from $11 \%$ to $30 \%{ }^{[25]}$.

Azevedo et al in a recent study published in 2012, found prevalence of $\mathrm{CP}$ in Portugal to be $36.7 \%$ (confidence interval [95\% CI] [35.3 - 38.2]), according to the IASP definition. Pain intensity was graded as mild in $32 \%$ of patients, moderate in $46 \%$, and intense in $22 \%$. Continuous or recurrent pain was present in $85 \%$ of cases with CP. The lower back and limbs were the most frequently affected locations, representing over two-thirds of cases. Regarding the cause of pain, the most frequent etiologies were osteoarthritis and osteoarthritis, pathologies of the spine and osteoporosis, which accounted for over two-thirds of individuals with CP. Cancer pain was present in 3\% of cases. With respect to duration of pain, people with CP had suffered for 10 years (average), but in $25 \%$ of cases the pain had existed for over 20 years ${ }^{[26]}$.

Several studies suggest that organic, demographic and cognitive factors also contribute differently to the increase in disability and increase in pain ${ }^{[1]}$. Hence Penido emphasises that the cognitive factors cannot be overlooked for they influence the perception, the development and the maintenance of CP. This is apparent in the attitudes, beliefs and expectations that each individual has in relation to themselves, as well as in the forms of access to care to control or eradicate the pain ${ }^{[18]}$. It was found that physical disability and emotional maladjustment depends more on psychosocial variables than biological aspects, by which social learning is crucial in order to understand and deal with pain. Psychosocial models, in addition to safeguarding the importance of socialization, highlight the role of culture in response to pain ${ }^{[1]}$.

In the cultural context, social learning and religion are factors which determine the meaning that individuals attach to pain. This influences how pain is regarded and influences the development of strategies to reduce its effects. When associated with religion, pain can be understood as a form of 'punishment' or 'redemption' or 'purification of the soul' ${ }^{[12]}$. Culture influences both the perception of pain and the way in which it is tolerated. Culture should not be assessed separately from the
A interferência da DC ao nível do bem-estar, nas relações familiares e sociais, e na vida profissional, resulta em alterações biológicas, psicossociais e em sofrimento ${ }^{[18]}$. Ou seja, quando associada a limitações físicas, profissionais e sociais a dor crónica compromete a qualidade de vida e promove a insegurança, resultando em perdas materiais e sociais consideráveis ${ }^{[10 ; 22]}$.

\section{Alguns Dados Objectivos Sobre a Realidade da Dor Crónica}

Em revisões sistemáticas as estimativas da prevalência da DC variaram de 2 a $55 \%{ }^{[23 ; 24]}$. Breivik et al encontraram, em quinze países europeus, uma prevalência de DC que variou entre $11 \%$ a $30 \%{ }^{[25]}$.

Azevedo et al num estudo recente, publicado em 2012, ventilaram uma prevalência de DC, em Portugal, de $36.7 \%$ (intervalo de confiança de $95 \%$ [CI] [35.3 38.2]), de acordo com a definição da IASP. A intensidade da dor foi classificada como ligeira em $32 \%$ dos indivíduos, moderada em $46 \%$, e intensa em $22 \%$. A dor recorrente ou contínua estava presente em $85 \%$ dos casos com DC. A região lombar e os membros eram as localizações mais frequentemente afectadas, representando mais de dois terços dos casos. Em relação às etiologias mais frequentes como causa da dor encontravam-se a osteoartrite e a osteoartrose, as patologias da coluna e a osteoporose, as quais representavam mais de dois terços dos indivíduos com DC. A dor oncológica estava presente em 3\% das situações. As pessoas com DC apresentavam queixas, no que diz respeito à duração da dor, há 10 anos (média), porém em $25 \%$ dos casos a dor existia há mais de $20 \operatorname{anos}^{[26]}$.

Vários estudos sugerem que os factores orgânicos, sociodemográficos e cognitivos também contribuem, de forma diferenciada, para o aumento da incapacidade e para o aumento da dor ${ }^{[1]}$, daí Penido reforçar que os factores cognitivos não podem deixar de ser considerados pois influenciam a percepção, o desenvolvimento e a manutenção da DC, revelando-se nas atitudes, crenças e expectativas que cada um tem em relação a si próprio, bem como nas formas de acederem a cuidados para controlo ou irradicação da dor ${ }^{[18]}$. Verificou-se que a incapacidade física e o desajuste emocional depende mais das variáveis psicossociais do que dos aspectos biológicos, pelo que a aprendizagem social é determinante na forma de entender e lidar com a dor. Os modelos psicossociais, além de salvaguardarem o contributo da socialização, dão enfoque destacado ao papel da cultura na resposta à dor ${ }^{[1]}$.

No contexto cultural a aprendizagem social e a religião são factores determinantes no significado que os indivíduos atribuem à dor, influenciando o modo 
whole social context in which the individual belongs. Neither should it be separated from life experiences and the internalized lifelong impact of society. The way individuals communicate their pain is also influenced by cultural standards, which define the way in which pain is appreciated and how pain and suffering manifest themselves ${ }^{[15,17]}$.

Several studies show that a low level of education affects access to information and has an impact on how individuals gain access to health care in pain management or prevention. The very low level of education, or, in most cases, almost complete lack of education, demonstrates the reality of the aging population. It reflects the recent past in which schooling was relegated at the expense of the labor and economic conditions of families ${ }^{[4]}$. The type of profession or occupation not only contributes to the economic situation of the individual and family, it also affects their social role ${ }^{[4,27]}$.

Individuals with low levels of schooling have a significant risk and markedly higher risk of suffering from $\mathrm{CP}$. The relationship between $\mathrm{CP}$ and the level of education is common, especially because education is a strong marker of the socio-economic status of an individual ${ }^{[28,29,30,31,32]}$.

Some authors reported a higher association of CP with the unemployed and pensioners ${ }^{[28,29,30,31,32]}$. The social and psychological changes associated with retirement can explain this. The association with unemployment is more complex: it can increase the risk of $\mathrm{CP}$, but the presence of CP can also trigger unemployment ${ }^{[33]}$.

In Portugal, the $\mathrm{CP}$ overload causes a high personal and social burden, and particularly affects vulnerable subgroups (the elderly, retired, unemployed and poorly educated). Incapacity caused by pain was present in $35 \%$ of cases, and the factors significantly and independently more often associated with it were: female gender, pain intensity, depressed mood and clinical diagnosis of depression. The diagnosis of depression, caused by $\mathrm{CP}$, had been done in $13 \%$ of persons ${ }^{[26]}$.

The interference of CP in work activity was reported in several studies ${ }^{[25,34,35,36,37]}$. In Portugal this impact arises in $49 \%$ of cases of CP. When evaluating the number of working days lost in the labor force in the previous 6 months, there was an average of 4.36 , but $9 \%$ had lost more than 10 days. The absences were often due to pain and the consequences were: job loss, change in job responsibilities, change of profession / job, early retirement, long-term sick leave ${ }^{[2]}$.

The indirect costs of CP (pains in the spine and joints) estimated for Continental Portugal, using wage costs for 2010, amounted to 738.85 million euros. 280.95 million of which was due to absenteeism generated by short-term incapacity and 458.90 million was due to the reduction in the volume of employment through como é encarada e na definição de estratégias para reduzir os seus efeitos. Quando associada à religião pode ser entendida como uma forma de "punição" ou "redenção", ou de "purificação da alma" ${ }^{[12]}$. A cultura, como elemento influenciador, não só da percepção da dor como na forma que é tolerada, não deve ser avaliada separadamente de todo o contexto social em que o indivíduo está inserido, nem dissociada das experiências de vida e de todas as influências da sociedade ao longo da vida interiorizadas. A forma como os indivíduos transmitem a sua dor também é influenciada pelos padrões culturais, os quais definem a valorização ou desvalorização e a forma de exteriorização da dor e do sofrimento ${ }^{[15 ; 17]}$.

Diversos estudos revelam que o baixo nível de escolaridade condiciona o acesso à informação, tendo repercussões na forma como os indivíduos acedem aos cuidados de saúde, no controlo da dor ou na sua prevenção. A escolaridade muito baixa e, na maioria dos casos, quase inexistente demonstra a realidade da população mais idosa e reflecte um passado recente, em que a escolaridade era relegada em detrimento do trabalho e das condições económicas das famílias ${ }^{[4]}$. O tipo de profissão ou de ocupação não só contribui para a situação económica do indivíduo e família, como interfere no seu papel social ${ }^{[4,27]}$.

Os indivíduos com escolaridade precária têm um risco significativo e marcadamente maior de sofrer de DC. A relação entre a DC e o nível educacional é comum, principalmente porque a instrução é um marcador forte do nível socio-económico de um indivíduo ${ }^{[28 ; 29 ; 30 ; 31 ; 32]}$.

Alguns autores relataram maior associação de DC a pessoas desempregadas e reformadas ${ }^{[28 ; 29 ; 30 ; 31 ; 32]}$. As mudanças sociais e psicológicas associadas com a reforma podem explicar este facto. A associação com o desemprego é mais complexa: este pode incrementar o risco de DC, mas a presença de DC pode desencadear desemprego, também ${ }^{[33]}$.

Em Portugal, a DC causa uma sobrecarga pessoal e social elevada, e afecta particularmente os subgrupos mais vulneráveis (idosos, aposentados, desempregados e reduzida escolaridade). A incapacidade motivada pela dor estava presente em $35 \%$ dos casos, sendo que os factores, significativa e independentemente, mais associados a ela eram: o sexo feminino, a intensidade da dor, o humor deprimido e o diagnóstico clínico de depressão. O diagnóstico de depressão, motivado pela DC, tinha sido feito em $13 \%$ das pessoas ${ }^{[26]}$.

A interferência da DC na actividade laboral foi referida em vários estudos ${ }^{[25 ; 34 ; 35 ; 36 ; 37]}$. Em Portugal esse impacto surge em 49\% das situações de DC. Ao avaliar o número de dias de trabalho perdidos na população activa, nos 6 meses precedentes, verificou-se uma média de 4.36, mas $9 \%$ tinha perdido mais de 10 dias. Os trabalhadores eram afectados, frequentemente, devido à dor por: perda do trabalho, mudança nas 
early retirement and other forms of non-participation in the labor market ${ }^{[38]}$.

Consistent results are published on the influence of psycho-aspects in how individuals perceive, express and deal with pain ${ }^{[1]}$. For example, unskilled and / or unstable jobs in many cases lead to a poor economic situation and hence insufficient resources to address the most pressing needs such as analgesia for pain control $^{[4,27]}$.

Several psychosocial factors can change the way women and men respond and react to pain, in particular affective stress and coping, and contribute to the existence of differences in how pain is experienced ${ }^{[9]}$. Studies in women found that they try to show that men are more sensitive to pain. They reported that men have a low tolerance and resistance to pain in comparison to the pains borne exclusively by women such as birth pains, menstrual and other. Nevertheless, there is a preconceived idea that women are taught to show their pain and their suffering more intensely than men. On the other hand men, when asked directly about this issue, say they are more resistant to pain because they are expected to have a strong stance without emotional manifestations ${ }^{[15]}$. Studies involving female victims of domestic violence have confirmed that although they concealed the attacks, the affects manifested themselves through specific and localized chronic pain, abdominal / pelvic pains and headache ${ }^{[1,6]}$.

\section{Pain, Symptomatology and Undertreatment}

Whilst pain is a clinical symptom, it becomes a serious public health problem because of its frequency and capacity to cause suffering and disability, in addition to the serious consequences on the personal, family and social level ${ }^{[9]}$. Pain is usually associated with illness, physical disability or highly significant losses such as body image. It is a very personal feeling that is hard to describe and measure, despite being experienced by most people ${ }^{[39]}$. responsabilidades profissionais, mudança de profissão/trabalho, reforma antecipada, baixa médica de longo prazo ${ }^{[26]}$.

Os custos indirectos da DC (dores na coluna e nas articulações) estimados para Portugal Continental, usando os custos salariais de 2010, ascendem aos 738,85 milhões de euros, sendo 280,95 milhões devidos ao absentismo gerado pela incapacidade de curto prazo e 458,90 milhões devidos à redução do volume de emprego por reformas antecipadas e outras formas de não participação no mercado de trabalho ${ }^{[38]}$. Estão publicados resultados consistentes sobre a influência dos aspectos psicossocioculturais no modo como o indivíduo percebe, expressa e lida com a dor ${ }^{[11]}$. Por exemplo, o facto de exercerem actividades não qualificadas e/ou precárias, representa em muitos casos, um rendimento económico precário e, consequentemente, insuficiente para colmatar as necessidades mais prementes como a analgesia para o controlo da dor ${ }^{[4 ; 27]}$.

Diversos factores psicossociais que podem alterar a forma como as mulheres e os homens respondem e reagem à dor, nomeadamente o stress afectivo e o coping, e que contribuem para a existência de diferenças no modo como experienciam a dor ${ }^{[9]}$. Em estudos realizados com mulheres verificou-se que as mesmas tentaram demonstrar que consideram que os homens são mais sensíveis à dor. Relataram a pouca tolerância e resistência à dor dando como exemplo as dores exclusivas das mulheres (dores do parto, menstruais e outras). Não obstante, há uma ideia préconcebida de que as mulheres são ensinadas a demonstrarem as suas dores e o seu sofrimento com mais intensidade que os homens. Por outro lado os homens, quando questionados directamente sobre esta assunto, afirmam serem mais resistentes à dor pois deles é esperada uma postura forte e sem manifestações emotivas ${ }^{[15]}$. Estudos envolvendo mulheres vítimas de violência doméstica confirmaram que estas mulheres, apesar de encobrirem as agressões, estas eram manifestadas através da apresentação de dores crónicas específicas e localizadas como, por exemplo, dores abdominais/pélvicas e cefaleias ${ }^{[1 ; 6]}$.

\section{Dor, Sintomatologia e Subtratamento}

A dor enquanto sintoma clínico, transformou-se num problema sério de saúde pública, pela sua frequência e capacidade de causar sofrimento e incapacidade, e pelas graves consequências ao nível pessoal, familiar e social ${ }^{[9]}$. Geralmente está associada a uma doença, à incapacidade física, ou a perdas de grande significado como a imagem corporal. É um sentimento muito íntimo, difícil de descrever e medir, apesar de ser vivenciado pela maioria das pessoas ${ }^{[39]}$. 
In order to treat or provide relief from $\mathrm{CP}$, it is essential to identify the factors that promote a clearer picture of the pain in order to predict its impact on a psychosocial and biological level, bearing in mind that when an individual is suffering from pain it may be unable to perform the activities of daily living ${ }^{[8]}$.

Currently there are several forms of treatment for the alleviation of CP. There remains a reluctance to use certain drugs, notably opiates. In the United States, despite the existence of extensive knowledge about the pain-relieving capacity of the opiate drugs (OD), it was found that their applicability is reduced ${ }^{[40]}$. The study aimed to recognize the factors which limit the use of OD in pain relief. Three inhibiting factors were identified: social barriers (OD intake is connected to a negative image linked to illegality); health professionals lack of knowledge about treatment of painful syndromes( this includes a lack of knowledge about physical and chemical dependence, or tolerance, which are not synonymous and are visibly distinct from each other); and the legal system ( on the one hand the law is vague and ambiguous and doctors are afraid when giving instructions; they therefore prescribe minimum doses and use it only as a last resort; on the other hand, the government's disinterest and misinformation allows for the provision of OD for the relief of pain) ${ }^{[40]}$. Thus, the use of OD as a pain control mainly for $\mathrm{CP}$, is conditioned by social, economical, legal, education, ethical and political issues, and this contribute to its prevalence ${ }^{[39,40]}$.

Nevertheless it is assumed that, at present, in addition to pharmacological interventions, there are nonpharmacological interventions that can be used in pain relief and control which take into account the physical, psychological and social aspects of the individual ${ }^{[8]}$. However, it is clear that given the complexity of this problem, no professional area can intervene comprehensively in all aspects involved in the treatment of pain, so a multidisciplinary approach is imperative. As such, collective work is essential in order to promote a comprehensive intervention ${ }^{[19,27]}$, which is able to identify potential elements of insecurity and loss of QOL. However, this approach is not easy due to the unique characteristics of each individual (physical, psychological, cognitive) and the sociocultural context in which they operate. Nevertheless there has been significant development in $\mathrm{CP}$ intervention when we consider the evolution from intervention of a biomedical nature to intervention based on multidisciplinary programs with psychosocial interventions in the field, which have proven efficacy ${ }^{[10,41,42]}$.
Para o tratamento ou alívio da DC é fundamental a identificação dos factores que promovem a melhoria de um quadro álgico de modo a antever as repercussões da dor ao nível biológico e psicossocial pois, perante a prevalência da dor, um individuo pode ser incapaz de realizar as suas actividades da vida diária ${ }^{[8]}$.

Actualmente existem várias formas de tratamento para o alívio da DC sendo que, continua a haver muita relutância na utilização de determinados fármacos, nomeadamente os opiáceos. Nos Estados Unidos da América, apesar da existência de amplos conhecimentos sobre a capacidade de alívio da dor dos fármacos opiáceos (FO) verificou-se que a sua aplicabilidade é reduzida ${ }^{[40]}$. No estudo realizado com o objectivo de reconhecer factores de condicionantes do uso de FO no alívio da dor, foram identificadas três factores inibidores - as barreiras sociais (o consumo de FO apresenta-se como um bloqueio social ligado a uma imagem negativa, a da ilegalidade), o desconhecimento dos profissionais de saúde sobre formas de tratamento das sindromes dolorosas (o desconhecimento sobre a dependência física, química ou tolerância que, apesar de sinónimas não são visivelmente distintas umas das outras) e o sistema legal (por um lado a lei é vaga e ambígua pelo que os médicos têm receio na sua indicação, recorrendo à prescrição de doses mínimas e em última instância, por outro lado os governantes demonstram desinteresse e desinformação de modo a permitirem a disponibilização de FO para o alivio da dor) ${ }^{[40]}$. Deste modo, o controlo a dor através do uso de FO, principalmente da DC, é condicionado por questões de ordem social, económica, legal, educacional, ética e política, contribuindo para que a mesma prevaleça ${ }^{[3 ; ; 40]}$.

Não obstante admite-se que, actualmente, além das intervenções farmacológicas, existem intervenções nãofarmacológicas que podem ser utilizadas no alívio e controlo da dor, e têm em conta os aspectos físicos, psíquicos e sociais do indivíduo ${ }^{[8]}$ embora seja claro que, dada a complexidade desta problemática, nenhuma área profissional possa intervir de forma abrangente, em todos os aspectos envolvidos no tratamento da dor, pelo que é fundamental uma abordagem multidisciplinar. Como tal, é essencial um trabalho colectivo, com o envolvimento de todos, de modo a promover uma intervenção completa ${ }^{[19 ; 27]}$, capaz de identificar elementos potencializadores de insegurança e de perda de QDV. Todavia, esta abordagem não se apresenta facilitada devido às especificidades únicas de cada indivíduo (físicas, psíquicas, cognitivas) e ao contexto sociocultural em que está inserido. Efectivamente é possível constatar uma evolução significativa ao nível da intervenção na $\mathrm{DC}$, considerando a evolução de uma intervenção de carácter biomédico para uma intervenção assente em programas multidisciplinares, com intervenções no campo psicossocial, com eficácia comprovada, principalmente no tratamento da $\mathrm{DC}^{[10 ; 41 ; 42]}$. 


\section{Conclusions}

$\mathrm{CP}$ is a major determinant of people's lives, interfering with daily life at various levels, whether physical, psychological, social or other. This conditioning may be reflected in the performance of basic daily activities, in the practice of a professional activity, in the performance of social roles and in all related fields, directly or indirectly, with the individual sufferer and the people around them.

According to several authors, the way each individual perceives pain is unique and influenced by sociocultural and demographic variables such as gender, age, religion, ethnicity, culture, family, and others. Among these, there is the remarkable influence of cultural factors and how pain is perceived, which determine the behavior of the individual when confronted with pain as it is based on the first experiences of the individual in that context. Factors such as how to openly express pain varies from culture to culture ranging from hiding pain to showing it openly. Education and family environment also play a substantial role in how people feel pain, because people tend to react the way they were taught.

It also clear that we should invest in the biopsychosocial model of pain, especially in $\mathrm{CP}$ intervention. This is because pain can hardly be just physical, psychological and social consequences are always implicit. The chronicity itself causes imbalances and limitations in the daily life of individuals and people with whom they interact, whether to a greater or lesser degree.

In the social field there should be an increased focus on possible biopsychosocial consequences, such as situations of isolation, social exclusion and the breakdown of relationships. However the monitoring and evaluation for physical signs should never be neglected because suffering, especially when prolonged, can lead to pain, in the same way that pain, when prolonged, can cause suffering ${ }^{[43]}$.

\section{Conflict of Interests}

The authors declare that they have no financial or personal relationships that could be construed as having potential conflicts of interest.

\section{Conclusões}

A DC é um condicionante principal da vida dos indivíduos, interferindo no quotidiano a vários níveis, sejam estes físicos, psíquicos, sociais ou outros. Este condicionamento pode reflectir-se no desempenho das actividades básicas diárias, no exercício de uma actividade profissional, no desempenho do seu papel social e em todos os outros campos relacionados, directa ou indirectamente, com o individuo que sofre e com as pessoas com quem se relaciona.

De acordo com vários autores, a forma como cada indivíduo percepciona a dor é única e influenciada por variáveis demográficas e socioculturais como género, idade, religião, etnia, cultura, ambiente familiar, e outras. Entre estas, destaca-se a influência marcante dos factores culturais e a forma como a dor é percepcionada, determinando o comportamento do indivíduo perante a dor, uma vez que tem por base as primeiras experiências do indivíduo nesse contexto. Tal como a forma de expressar abertamente a dor é variável de cultura para cultura, sendo que podem esconder ou demonstra-la abertamente, também a educação e o ambiente familiar têm um papel substancial na forma como se sente a dor, pois as pessoas tendem a reagir da forma como foram ensinadas.

Resulta também claro que importa investir na abordagem biopsicossocial da dor, em especial na intervenção na DC, pois esta só dificilmente pode ser apenas física, tendo sempre implícitas consequências psicológicas e sociais. A própria cronicidade provoca desequilíbrios e limitações no quotidiano dos indivíduos e das pessoas com que eles se relacionam, independentemente de ser em maior ou menor grau.

No campo social deve haver uma atenção redobrada sobre eventuais consequências biopsicossociais, como situações de isolamento, de desvinculo e de exclusão social. No entanto nunca deve ser descurada a vigilância e avaliação dos sinais físicos porque o sofrimento, principalmente quando prolongado, pode conduzir à dor; tal como a dor, quando prolongada, pode causar sofrimento ${ }^{[43]}$.

\section{Conflito de Interesses}

Os autores declaram que não têm relações financeiras ou pessoais que possam ser entendidas como apresentando potenciais conflitos de interesse. 


\section{References / Referências}

[1]. Júnior JJS, Nicholas MK, Pimenta CAM, Asghari A. Preditores biopsicossociais de dor, incapacidade e depressão em pacientes brasileiros com dor crónica. Rev. Dor (São Paulo) 2012;13(2):111-8.

[2]. Associação Portuguesa para o Estudo da Dor. O que é a dor? Disponivel e m http://www.apeddor.com/index.php?lop=conteudo\&op $=\mathrm{d} 67 \mathrm{~d} 8 \mathrm{ab} 4 \mathrm{f} 4 \mathrm{c} 10 \mathrm{bf} 22 \mathrm{aa} 353 \mathrm{e} 27879133 \mathrm{c}$. Acedido em 11 de Novembro de 2012.

[3]. Rabelo DF, Cardoso CM. Auto-eficácia, doenças crônicas e incapacidade funcional na velhice. Psico-USF 2007;12 (1):75-81

[4]. Celich KLS, Galon C. Dor crônica em idosos e sua influência nas atividades da vida diária e convivência social. Rev. Brasileira Geriatria Gerontologia 2009; 12 (3):345-59.

[5]. Mayrink WC, Cunha LL. Influência da dor crônica na qualidade de vida em idosos. Ver. Dor (São Paulo) 2011;12:120-4.

[6] .de Andrade FA, Pereira LV, Sousa FF, Aparecida E. Mensuração da dor no idoso: uma revisão. Rev Latinoam Enferm. 2006;14 (2):271-6.

[7]. Gameiro MH. "Estar doente": Atribuição pessoal de significações. Revista de Enfermagem, 2004; 12( I série):35-43.

[8].Yeng, LT et al. Avaliação funcional do doente com dor crônica. Revista de Medicina, 2001;80(ed especial pt I):443-73.

[9].Dias, M. No quotidiano da dor: A procura dos cuidados de saúde. Análise Psicológica, 2002;1(XX):91-105.

[10]. Martins, LM., França, AP., \& Kimura M. Qualidade de vida de pessoas com doença crônica. Rev Latinoam Enferm.1996;4(3):5-18.

[11]. Pimenta, CA. Dor crônica, terapia cognitiva comportamental e o enfermeiro. Revista de Psiquiatria Clinica, 2001; 28(6):288-294.

[12] .Pimenta, C. \& Portnoi, A. Dor e Cultura. In Carvalho, M.(Ed), Dor: um Estudo Multidisciplinar 1999; 159-173.

[13]. Oliveira, J.T. Aspectos comportamentais das sindromes de dor crónica. Arq Neuropsiquiatria 2000;58(2-A):360-365

[14]. Rezende, VL. Revisão crítica dos instrumentos utilizados para avaliar aspectos emocionais, físicos e sociais do cuidador de pacientes com câncer na fase terminal da doença. Revista Brasileira de Cancerologia, 2005;51(1):79-87.

[15]. Budó, MLD. et al. A cultura permeando os sentimentos e as reações frente à dor. Rev. Esc. Enferm. 2007;41(1):36-47.
[16]. Andrade FA, Pereira LV, Sousa FAEF Mensuração da dor no idoso: uma revisão. Rev Latino-am Enfermagem; 2006 (mar-abr);14(2): 271 6.

[17]. Kurita, GP., \& Pimenta, CA. Adesão ao tratamento da dor crónica - Estudo de variáveis demográficas,terapêuticas e psicossociais. Arq Neuropsiquiatr 2003;61(2-B):416-425

[18]. Penido, MA. A influências das habiliades sociais em pacientes fibomiálgicas. Rio de Janeiro. Dissertação (mestrado) 2004- Universidade Federal do Rio de Janeiro, Instituto de psicologia.

[19]. Abreu-Rodrigues, M., \& Seidl, EM. A importância do apoio social em pacientes coronarianos. 2008;18(40):279-288.

[20]. Teixeira, JAC., \& Correia, A.R.. Fragilidade social e psicologia da saúde: Um exemplo de influências do contexto sobre a saúde. Análise Psicológica, 2002; 3, (XX), 359-365.

[21]. Makluf, AS. Avaliação da qualidade de vida em mulheres com câncer da mama. Rev Brasileira Cancerologia (Revisão de Literatura-Qualidade de vida em mulheres com câncer da mama). 2006;52(1):49-58.

[22]. Yeng, LT. Dor: Manual para o Clínico, Medicina Física e Reabilitação em Doentes com Dor Crônica. 2001;13:113-125.

[23]. Ospina M, Harstall C. Prevalence of chronic pain: an overview. Health Technology Assessment, 28th Report. Edmonton, Canada: Alberta Heritage Foundation for Medical Research, 2002.

[24]. Verhaak PF, Kerssens JJ, Dekker J, Sorbi MJ, Bensing JM. Prevalence of chronic benign pain disorder among adults: a review of the literature. Pain 1998; 77:231-9.

[25]. Breivik H, Collett B, Ventafridda V, Cohen R, Gallacher D. Survey of chronic pain in Europe: Prevalence, impact on daily life, and treatment. Eur J Pain 2005; 10:287-333.

[26]. Azevedo LF, Costa-Pereira A, Mendonça L, Dias CC, Castro-Lopes JM. Epidemiology of chronic pain: a population-based nationwide study on its prevalence, characteristics and associated disability in Portugal. J Pain 2012;13(8):773-83.

[27]. Tamborelli, V. O papel da enfermagem e da fisioterapia na dor em pacientes geriátricos terminais. Rev Geriatria \& Gerontologia. 2010;4(3):146-153

[28.] Elliott AM, Smith BH, Penny KI, Smith WC, Chambers WA. The epidemiology of chronic pain in the community. Lancet 1999;354:1248-52.
[29]. Eriksen J, Jensen MK, Sjogren P, Ekholm O, Rasmussen NK. Epidemiology of chronic nonmalignant pain in Denmark. Pain 2003;106:221-8. [30]. Johannes CB, Le TK, Zhou X, Johnston JA, Dworkin RH. The prevalence of chronic pain in United States adults: Results of an internet-based survey. J Pain 2010;11:1230-9.

[31].Wong WS, Fielding R. Prevalence and characteristics of chronic pain in the general population of Hong Kong. J Pain 2011; 12:236-45.

[32].Yu HY, Tang FI, Kuo BI, Yu S. Prevalence, interference, and risk factors for chronic pain among Taiwanese community older people. Pain Manag Nurs 2006;7:2-11.

[33]. Blyth FM, March LM, Brnabic AJ, Jorm LR, Williamson M, Cousins MJ. Chronic pain in Australia: a prevalence study. Pain 2001;89:127-34.

[34]. Blyth FM, March LM, Nicholas MK, Cousins MJ. Chronic pain, work performance and litigation. Pain 2003;103:41-7.

[35]. Catala E, Reig E, Artes M, Aliaga L, Lopez JS, Segu JL. Prevalence of pain in the Spanish population: Telephone survey in 5000 homes. Eur J Pain 2002;6:133-40.

[36]. Latham J, Davis BD. The socioeconomic impact of chronic pain. Disabil Rehabil 1994;16:39-44.

[37]. Maniadakis N, Gray A. The economic burden of back pain in the UK. Pain 2000;84:95-103.

[38]. Gouveia M, Augusto M. Custos indirectos da dor crónica em Portugal. Rev. Portuguesa de Saúde Pública, 2011;29(2):100-7.

[39]. Pimenta, CA. Opiácio Intratecal na Dor Crónica não Neplásica - Alívio e qualidade de vida. Arq. Neuropsiquiatria 1998;56(3-A):398-405.

[40]. Kipel, AG. Prevalência da dor: mitos, medos e desacertos relacionados ao uso de analgésicos opiáceos. Texto \& Contexto Enfermagem, 2004 (abr-jun);13(2):303-8.

[41]. da Costa, DAP. O efeito do treinamento contra resistência. Revista Portuguesa de Ciências do Desporto, 2005;5(2):224-34.

[42]. Püschel, VA. Modelos clínicos e psicossocial de atenção ao indivíduo e à família na assistência domiciliar - bases conceituais. Rev. Esc. Enferm. 2006;40(2):261-8

[43]. Ferreira, F. d. et al.; Sofrimento de mulheres mastectomizadas submetidas a quimioterapia. Revista Referência II; 2009;10:65-76. 